THE ART INSTITUTE OF CHICAGO

$\mathrm{N}$

$53 \varnothing$

A75X

NMAA

HE WALTER H. SCHULZE $\checkmark$ ALLERY OF AMERICAN PAINTINGS

FOUNDED I N 1924, G A L LER Y 47 


\section{CATALOGUE OF}

\section{THE WALTER H. SCHULZE GALLERY OF AMERICAN PAINTINGS}

\section{SEP 251990}





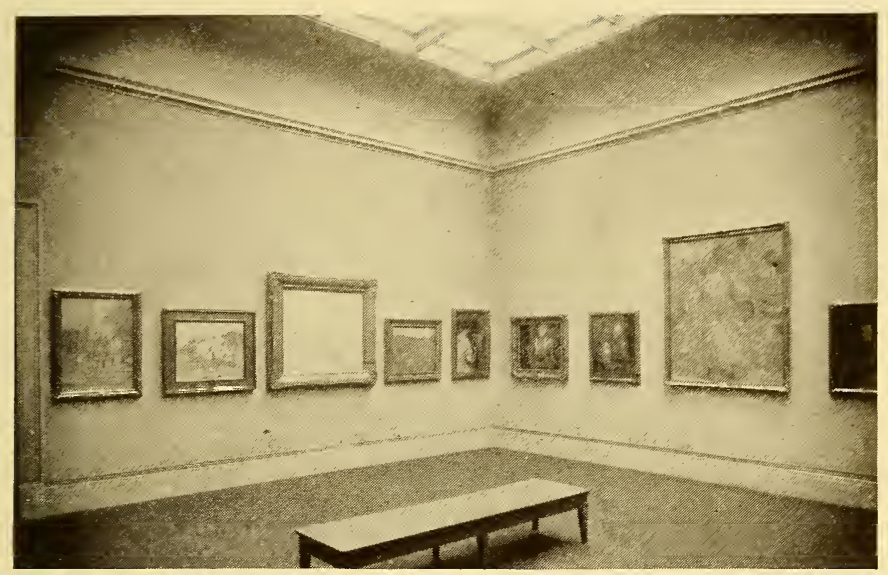

GALLERY LOOKING NORTHEAST

\section{THE WALTER H. SCHULZE GALLERY OF AMERICAN PAINTINGS}

Captain Walter H. Schulze, son of Mr. and Mrs. Paul Schulze, of Chicago, was graduated from West Point in the Class of 1917.

In the World War he was assigned to the Air Service. On the day of the signing of the Peace Treaty, which terminated the great struggle, he was given the honor of carrying news of the inspiring event to the American forces east of the Rhine. After delivering his message, his plane became unmanageable and crashed to the ground, resulting in his death.

In memory of their son Walter, Mr. and Mrs. Paul Schulze have given to the Art Institute the group of American Paintings shown herein. They have been suitably installed in Gallery 47. 


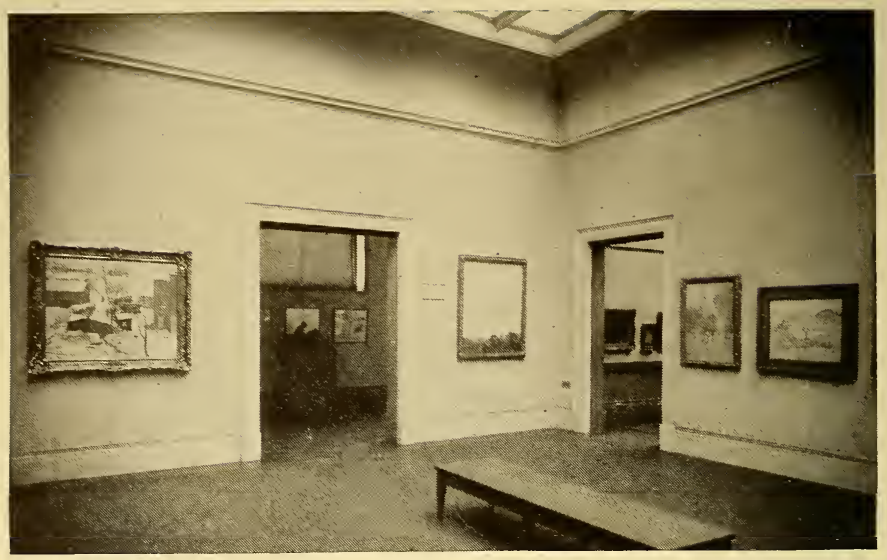

GALLERY LOOKING NORTHWEST 


\section{PAINTINGS IN THE WALTER H. SCHULZE GALLERY}

Artist

Tithe

Emil Carlsen - - - - The Miraculous Draught Bruce Crane - Early Winter, Westchester County, N. Y. Charles H. Davis - - - - The Northwest Wind Frederick C. Frieseke - $\quad$ - $\quad$ - Lady Trying on a Hat Childe Hassam - The Cathedral Spires, Spring Morning Childe Hassam - - _ _ _ - - The Willows Robert Henri - - - - - - - - Himself Robert Henri - - - - - - - - Herself W. L. Lathrop - - - - - - - Golden Fields William Ritschel - - - - - The Play of the Waves W. Elmer Schofield - The Power House, Falls Village, Conn. J. Alden Weir - - - - - - - Lute Player Guy C. Wiggins - - - - Snow-Crowned Hills J. H. Twachtman - - - - - - - Gloucester F. Ballard Williams - _ _ _ - Fete by the Lake 


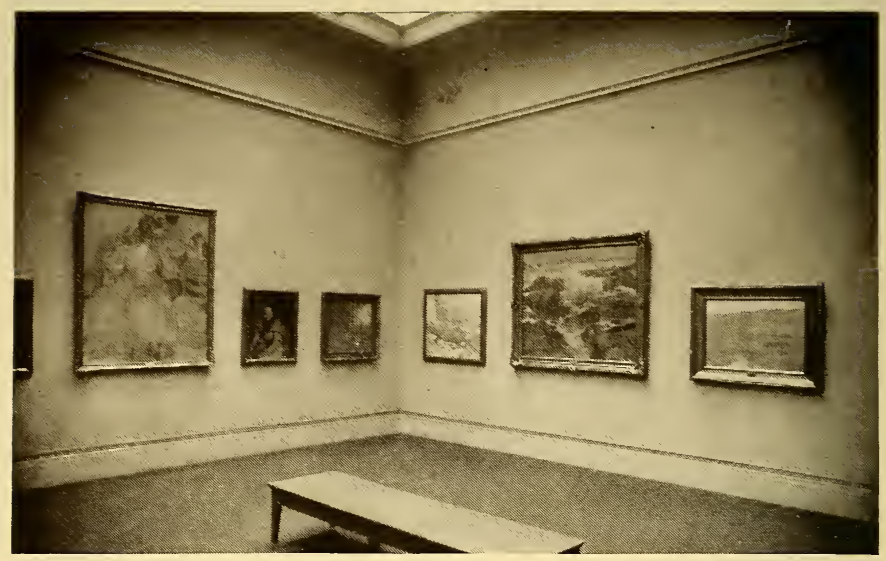

GALLERY LOOKING SOUTHEAST 


\section{ABBREVIATIONS}

AAA-Art Alliance of America.

A. Aid S-Artists Aid Society.

AFAS-American Fine Arts Society.

A. Fund S-Artists Fund Society, New York.

AIA-American Institute of Architects.

AIC-Art Institute of Chicago.

ANA-Associate National Academy of Design, New York.

Am. PS-American Painters and Sculptors.

ASL of NY-Art Students League of New York.

AWCS-American Water Color Society, New York.

Boston AC-Boston Art Club.

CI Pittsburgh-Carnegie Institute, Pittsburgh.

Chicago AC-Arts Club of Chicago.

Chicago SA-Chicago Society of Artists.

Conn. AFA-Connecticut Academy of Fine Arts, Hartford.

Corcoran AG-Corcoran Art Gallery, Washington, D. C.

Inter. Soc. AL-International Society Arts and Letters.

NA-National Academy of Design (Academicians).

NAC-National Arts Club, New York

NAD-National Academy of Design, New York.

Nat. Gal.--National Gallery, Washington, D. C.

NYWCC-New York Water Color Club.

PAFA-Pennsylvania Academy of the Fine Arts.

Paris AAA-American Art Association of Paris.

P. P. Exp.-Panama Pacific Exposition, San Francisco.

Port. P-National Association of Portrait Painters.

SAA-Society of American Artists.

Salma. C-Salmagundi Club, New York.

Ten Am. P-Ten American Painters, New York. 


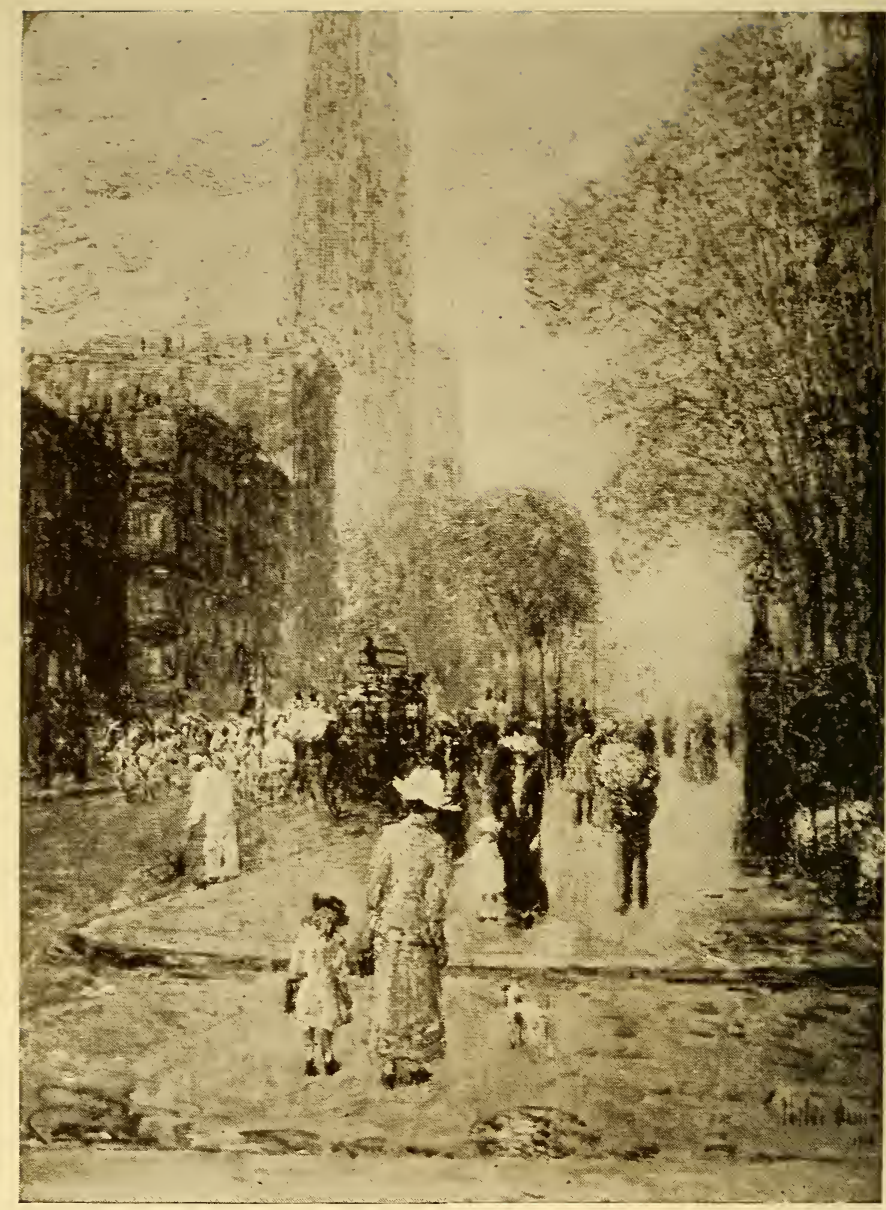

THE CATHEDRAL SPIRES, SPRING MORNING

HASSAM 


\section{CHILDE HASSAM}

Childe Hassam was born in Boston, October I7, I859. He was a pupil of Boulanger and Lefebvre in Paris. A member of ANA I902; NA 1906; AWCS; NYWCC; Boston AC; Ten Am. P.; Munich Secession (cor.); Assoc. Soc. Nat. des Beaux-Arts; Nat. Inst. A. L.

Awards: Bronze medal, Paris Exp., I 889; gold medal, Munich, I892; medal, AC Phila. I 892; bronze medal Columbian Exp., Chicago, I893; prize, Cleveland Art Assoc. I 893; Webb prize, SAA I895; prize, Boston AC I896; second class medal, C. I., Pittsburg, I 898; Temple gold medal, PAFA I899; silver medal, Paris, Exp. I900; gold medal, Pan-Am. Exp., Buffalo, I90I ; gold medal, St. Louis Exp., I904; Clarke prize, NAD I905; third class medal, C. I. Pittsburgh, I905; Lippincott prize, PAFA I906; Carnegie prize, SAA I906; third prize, Worcester, I906; Sesnan gold medal, PAFA, I9I0; third W. A. Clark prize, Corcoran AG I9Io; Evans prize, AWCS I9I2 ; first W. A. Clark prize $(\$ 2,000)$ and Corcoran gold medal, Washington, I9I2.

WORK: "Isles of Shoals" and "Golden Afternoon, Oregon," Metropolitan Museum, New York; "Northeast Headlands-New England Coast," and "New York Window,"

Corcoran Gallery, Washington; "Pont Royal," "The Caulker" and "House on the Place Lannion," Cincinnati Museum ; "Fifth Avenue in Winter," and "Spring Morning," also set of twenty-nine drawings, Carnegie Institute, Pittsburgh; "Summer Sea," Museum of Art, Toledo; "Church at Old Lyme," Fine Arts Academy, Buffalo; "The Messenger Boy" and "Street Scene" Rhode Island School of Design, Providence; "The Breakfast Room, New York" and "Sylph's Rock, Appledore," Worcester Art Museum ; "SpringNavesink Highlands" and "The Georgian Chair" (Evans Col.) and "The Chinese Merchants," (Freer Col.) National Gallery, Washington; "Cat Boats-Newport," Pennsylvania Academy, Phila "Cliffe Rock-Appledore, "Art Association, Indianapolis; "Place Centrale and Fort Cabana, Havana," Museum of Art, Detroit; "Contre-Jour," Art Institute, Chicago; "Isle of Shoals," Minneapolis Institute of Arts; "View of Central Park," Brooklyn Institute Museum; "Diamond Cove, Isle of Shoals," City Art Museum, St. Louis. 


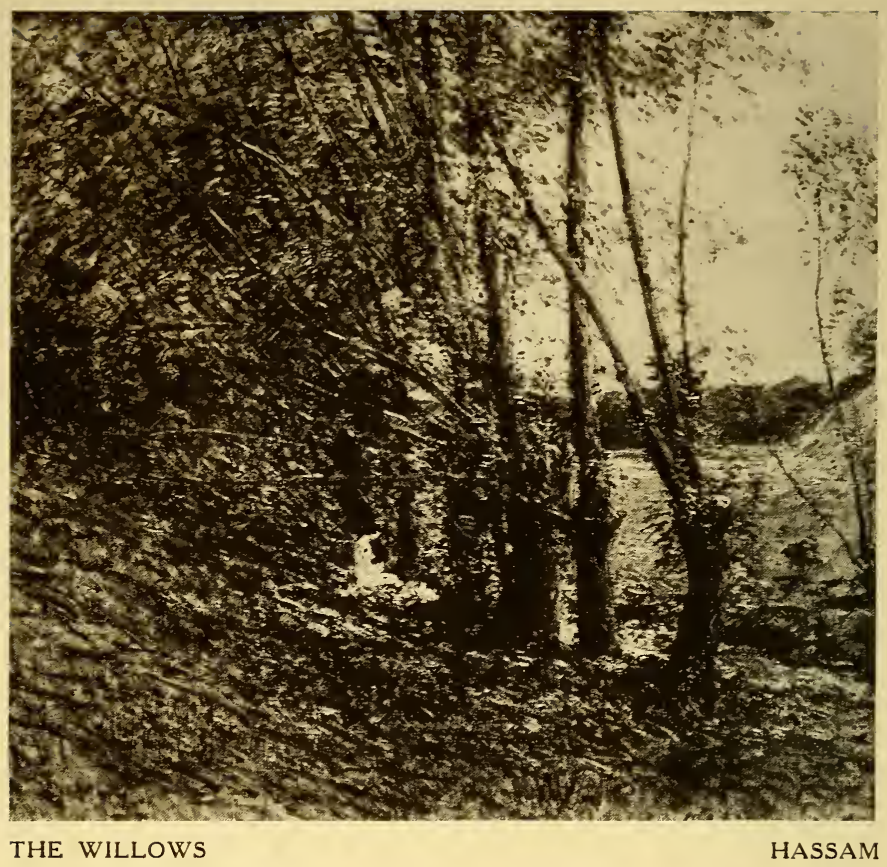




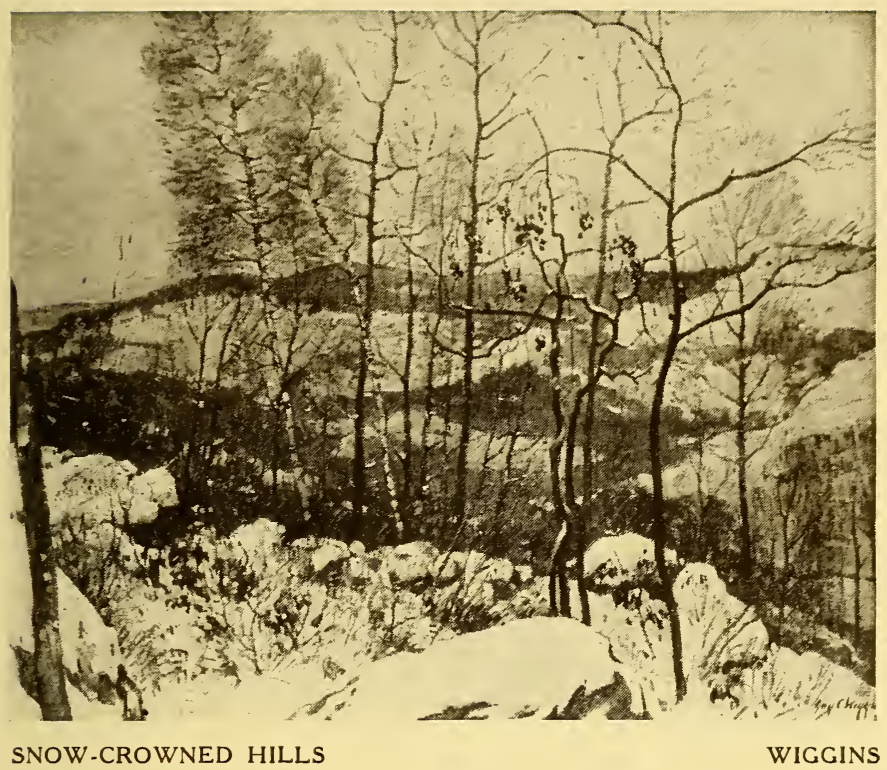

\section{GUY C. WIGGINS}

Guy C. Wiggins was born in Brooklyn, N. Y., February 23, 1883. He was a pupil of his father, Carleton Wiggins and of NAD in New York. A member of Salma. C.; Conn. AFA; Lotos C.; NAC.

WORK: "The Metropolitan Tower," Metropolitan Museum, New York: "Columbus Circle-Winter" and "Gloucester Harbor," National Gallery, Washington; "Berkshire Hills-June," Brooklyn Institute Museum; "Old North Docks," Hackley Art Gallery, Muskegon, Michigan. 


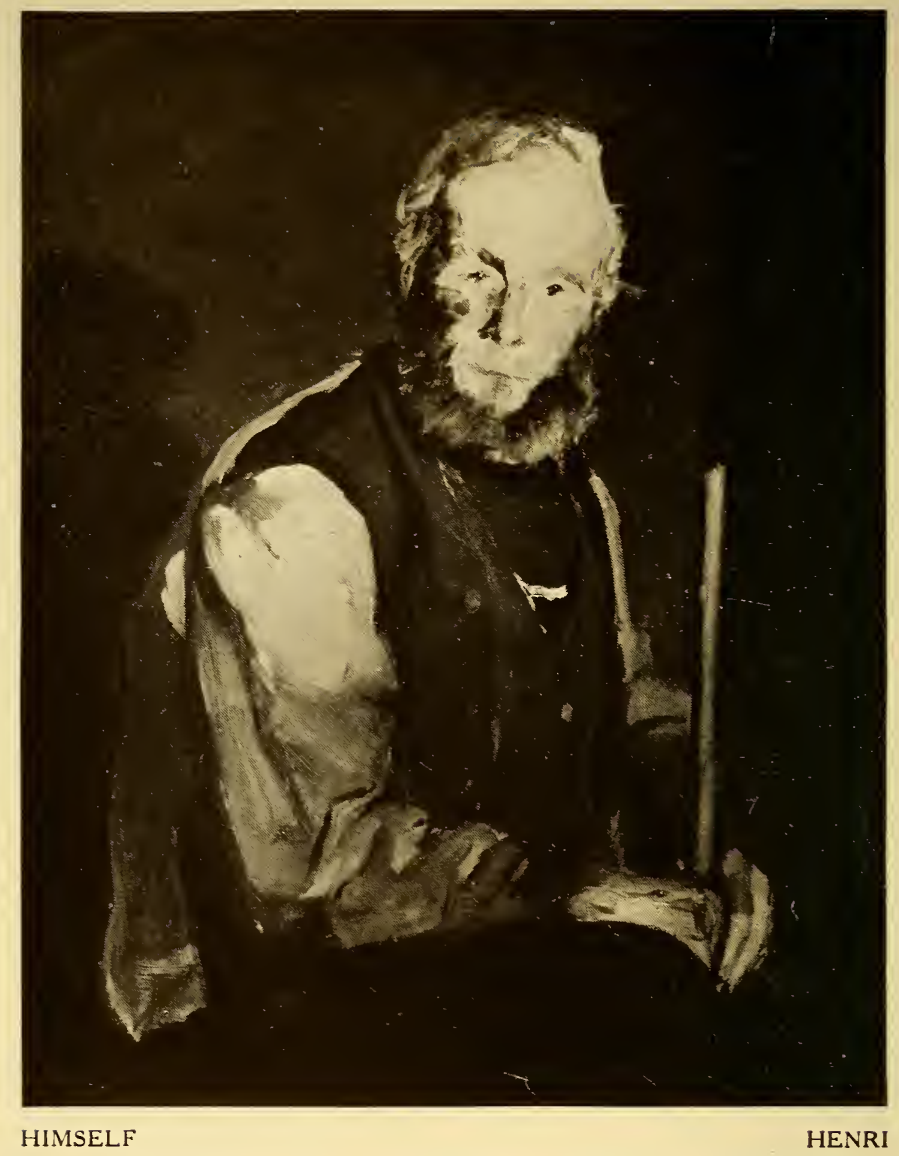




\section{ROBERT HENRI}

Robert Henri was born in Cincinnati, Ohio, June 24th, I 865. He was a pupil of PAFA; Julian Academy and Ecole des Beaux-Arts in Paris; studied in Spain and Italy. Member of SAA I903; ANA I904; NA I906; Nat. Inst. A. L.; Port. P.: Fellowship PAFA; MacD. C.; NAC (life) ; N. Y. Municipal AS. Am. PS.

Awards: Silver medal, Pan-Am. Exp., Buffalo, igor ; silver medal, St. Louis Exp., I904; Harris prize (\$500), AIC I905; gold medal AC Phila., I909; silver medal, Buenos Aires Exp., I9I0; Beck medal, PAFA I9I4; silver medal, P.-P. Exp., San Francisco, I9I5.

Work: "La Neige," Luxembourg Gallery, Paris; "Young Woman in Black," Art Institute of Chicago; "The Equestrian," Carnegie Institute, Pittsburgh; "Girl with Red Hair," Gallery of Spartanburg, S. C.; "Happy Hollander," Art Association, Dallas, Tex.; "Dancer in Yellow Shawl," Gallery of Fine Arts, Columbus, Ohio; "Spanish Gypsy Girl," Art Association, New Orleans; "Laughing Girl" and "Landscape" Brooklyn Institute Museum; "Girl with Fan," Pennsylvania Academy, Phila.; "Girl of Toledo," Carolina Art Association, Charleston, S. C.; "The Blue Necklace," Art Institute of Kansas City; "Lillian," San Francisco Institute of Art; "The Spanish Gipsy," Metropolitan Museum, New York; "Romany Girl," National Arts Club, New York; "Portrait of a Boy," Minneapolis Institute of Arts. 


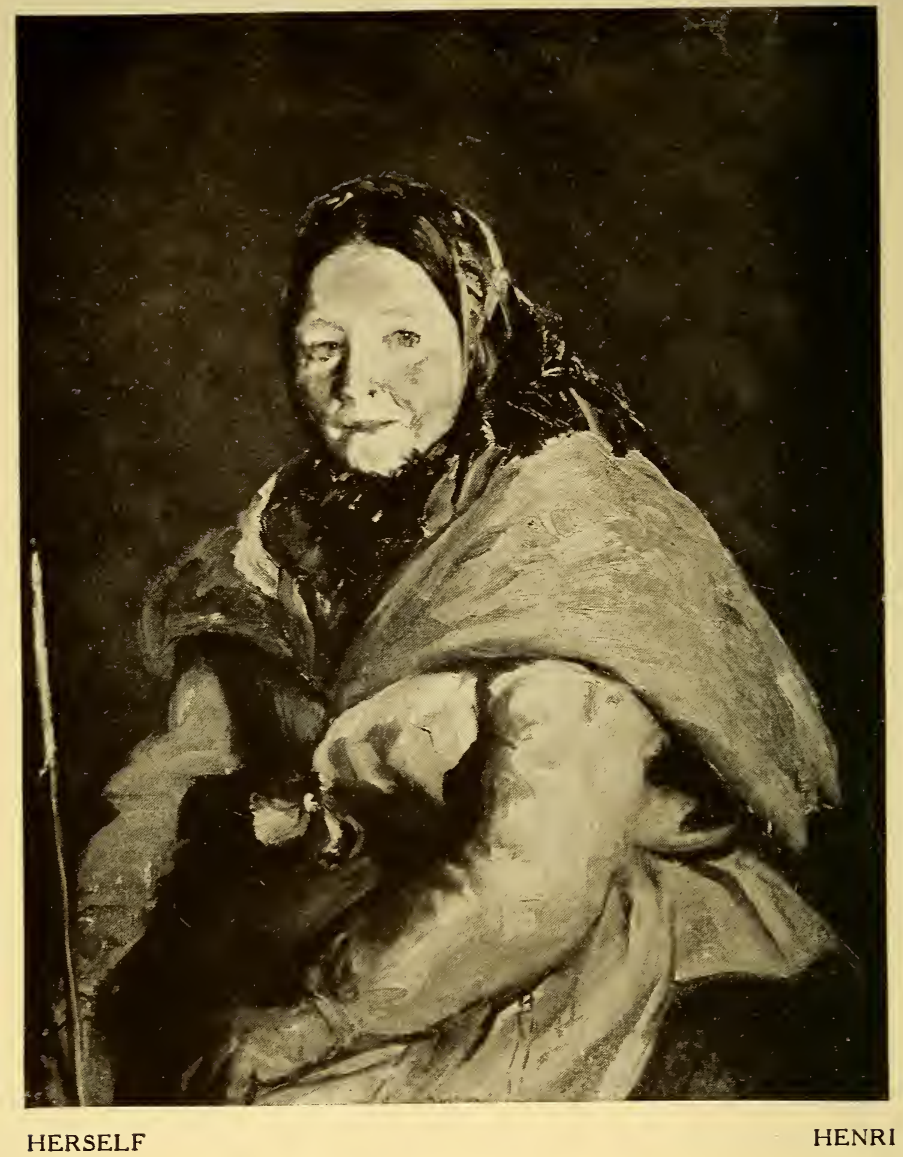




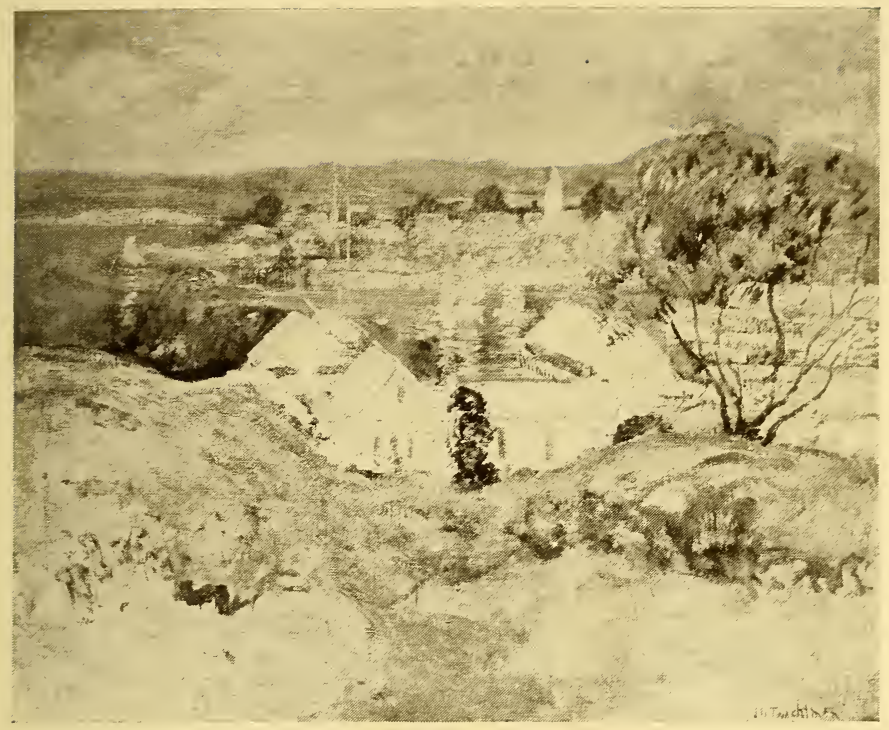

GLOUCESTER

TWACHTMAN

\section{JOHN H. TWACHTMAN}

John Henry Twachtman was born in Cincinnati, Ohio, August 4, 1853. He studied art under Frank Duveneck and afterwards spent some time studying in Paris. In 1879 he became a member of the Society of American artists, which he later abandoned to become a member of the society of Ten American Painters. His style is largely impressionistic. In I 893 he received the Webb prize for his painting "The Windmill." In I 895 he was awarded the Gold Medal of the Pennsylvania Academy of the Fine Arts and in I9or won the Gold Medal of the Buffalo Exposition. He died at Gloucester, Mass., August 8, 1902. 


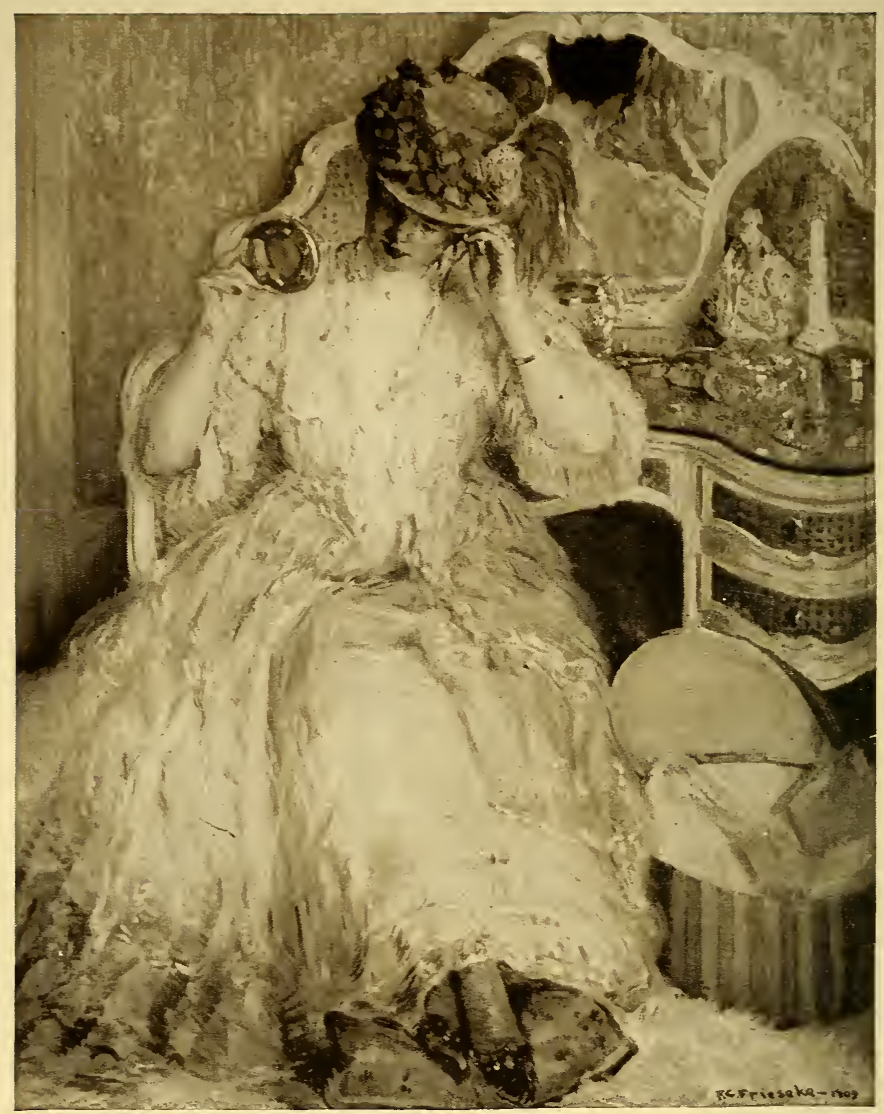

LADY TRYING ON A HAT

FRIESEKE 


\section{FREDERICK C. FRIESEKE}

Frederick Carl Frieseke was born in Owosso, Michigan, April 7, 1874. He was a pupil of AIC; ASL of N. Y.; Constant, Laurens and Whistler in Paris. A member of ANA 1912, NA 1914; Assoc. Soc. Nat. des Beaux-Arts, Paris AAA; Inter. Soc. AL.

Awards: Silver medal, St. Louis Exp., 1904; gold medal, Munich, 1904; fourth W. A. Clark prize $(\$ 500)$, Corcoran AG 1908; Temple gold medal, PAFA 1913; gold medal of honor, P.-P. Exp., San Francisco, 1915.

Work: "Before the Mirror," Luxembourg Museum, Paris; "The Toilet," Metropolitan Museum, New York; "On the Bank," Art Institute, Chicago; "Garden in June," Minneapolis Institute of Arts; and in Telfair Academy, Savannah, Ga.; Modern Gallery Venice, Italy; Museum of Odessa; Museum of Fine Arts, Syracuse, N. Y. 


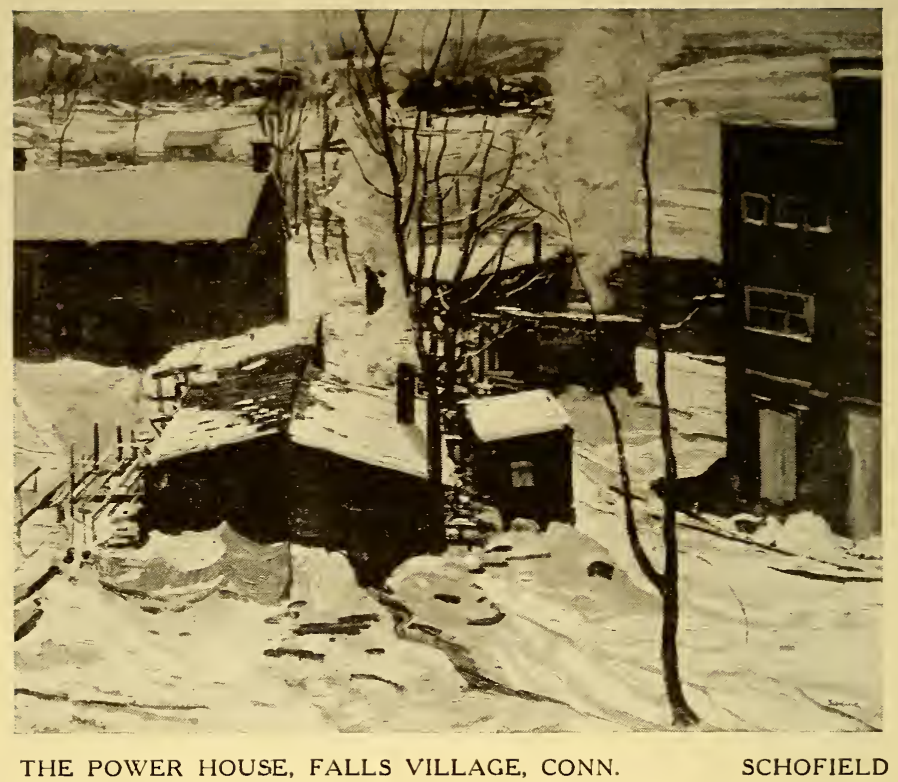




\section{WALTER ELMER SCHOFIELD}

Walter Elmer Schofield was born in Philadelphia, September 9, I867. He was a pupil of PAFA; Bouguereau, Ferrier, Doucet and Aman-Jean in Paris. A member of SAA 1904; ANA I902; NA I907; Nat. Inst. A. L.; AC Phila.; Fellowship PAFA; Century Assoc.; NAC; Salma. C.; R. S. British Artists; Chelsea Ärts Club, London.

Awards: Hon. mention, AC Phila. 1898; Webb prize, SAA I900; hon. mention, Paris Exp., I900; hon. mention, CI Pittsburgh, I900; first Hallgarten prize, NAD I90I; silver medal, Pan-Am. Exp., Buffalo, I90 ; Sesnan gold medal, PAFA I903; gold medal of honor $(\$ 1,500)$, CI Pittsburgh, I904; silver medal, St. Louis Exp., I904 Inness gold medal, NAD I9I I; gold medal and \$I,ooo, NAC I9 I 3 ; Temple gold medal, PAFA igi4.

Work: "Sand Dunes near Lelant," Metropolitan Museum, New York; "Morning After Snow," Corcoran Gallery, Washington; "Midwinter Thaw, Morning" and "Landing Stage, Boulogne," Cincinnati, Museum; "Across the River," Carnegie Institute, Pittsburgh; "Autumn in Brittany," Albright Art Gallery, Buffalo; "Winter," Pennsylvania Academy, Philadelphia; "Old Mills on the Somme," Art Association, Indianapolis; "'The White Frost," Memorial Gallery, Rochester, N. Y.; "The Coffer Dam," Art Institute of Chicago; "The Spring Thaw," National Arts Club, New York. 


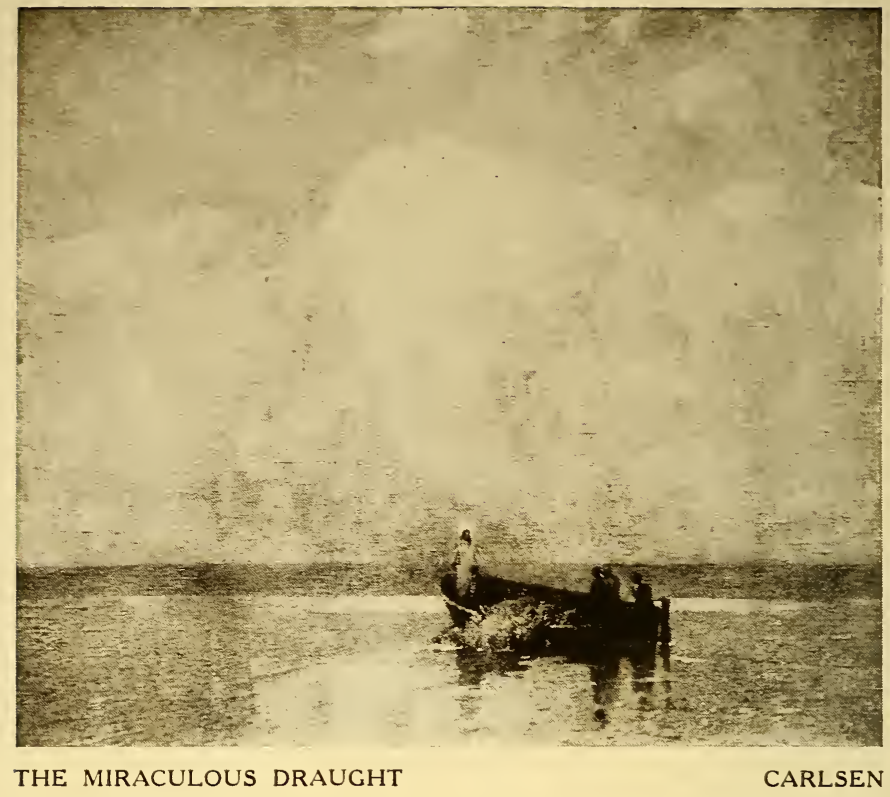




\section{EMIL CARLSEN}

Emil Carlsen was born in Copenhagen, Denmark, October 19, I853; came to United States in I872. Studied architecture at Danish Royal Academy. He was a member of SAA I902; ANA 1904, NA 1906; Nat. Inst. AL; NAC; Lotos C.; Salma. C. I903.,

Awards: Second Inness prize, Salma. C. 1904; Shaw Purchase, SAA 1904; gold medal, St. Louis Exp., 1904; Webb prize, SAA 1905; Inness medal, NAD 1907; third medal, C. I. Pittsburgh, 1908; Temple gold medal, PAFA I912; Lippincott prize $(\$ 300)$. PAFA I9I3; silver medal, NAC 1915; medal of honor, P.-P. Exp., San Francisco, I91 5. Work: "The Open Sea," "Surf," and "Still Life," Metropolitan Museum, New York; "Moonlight on the Kattegat," Buffalo Fine Arts Academy; "Morning," Rhode Island School of Design, Providence; "The South Strand," National Gallery, Washington; "The Lazy Sea," Brooklyn Institute Museum; "Still Life," (Kitchen Utensils), Art Institute, Chicago; "Open Sea," Minneapolis Institute; "Still Life," Herron Art Institute, Indianapolis; "Still Life," Art Museum, Worcester Mass.; "Summer Clouds" Pennsylvania Academy of the Fine Arts, Philadelphia. 


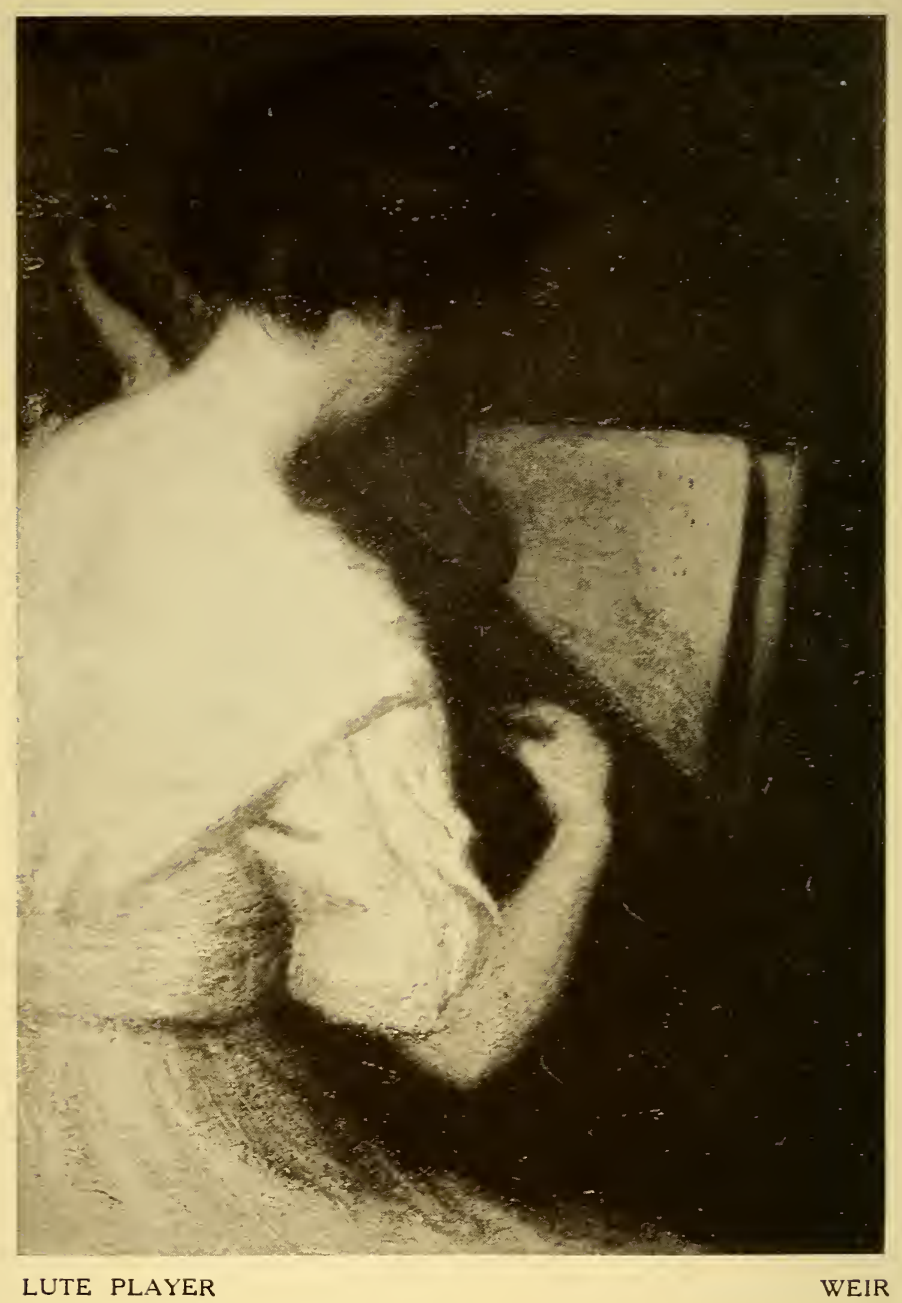




\section{JULIAN ALDEN WEIR}

Julian Alden Weir was born in West Point, New York, August 30 hh, I852. He was a pupil of his father, Robert W. Weir, at West Point; Gérôme in Paris. Member of ANA I 885; NA I 886 (pres. I9I 5-) ; AWCS; Ten Am. P.; N. Y. Etching C.; Conn. AFA; Lotos C.; A. Aid S.; Century Assoc.; Nat. Inst. A. L.

Awards: Hon. mention, Paris Salon, 1882; silver medal for painting and bronze for drawing, Paris Exp., I 889; prize $(\$ 2,000)$, American Art Assoc., New York; medal, C. I. Pittsburgh, I897; bronze medal, Paris Exp., I900; gold medal for paintings and silver for engravings, St. Louis Exp., I904; Inness medal Pan-Am. Exp., Buffalo, I90 ; gold medal, NAD I906; Lippincott prize, PAFA I910; Harris silver medal and \$500, AIC I912; Beck medal, PAFA 1913; first W. A. Clark prize $(\$ 2,000)$ and Corcoran gold medal, 1914; hors concours (jury of awards) P. P. Exp., San Francisco, I9I 5.

Work: "The Green Bodice," "Idle Hours" and "The Red Bridge" Metropolitan Museum, New York; "The Grey Bodice," Art Institute of Chicago ; "Early Morning," Albright Art Gallery, Buffalo; "Interior with Figure," Rhode Island School of Design, Providence; "An American Girl," Worcester Museum; "A Gentlewoman," Wyatt Eaton," "Upland Pasture," National Gallery, Washington; "Midday Rest in New England," Pennsylvania Academy, Philadelphia; "The Flower Seller," Brooklyn Institute Museum; "Ploughing for Buckwheat" Carnegie Institute, Pittsburgh; "Autumn" and "Portrait of Miss deL.," Corcoran Gallery Washington, D. C.; "A Glimpse of the Sound," Art Museum, Montclair, N. J.; 47 etchings, Cincinnati Museum; "Portrait of a Young Girl," Luxembourg Museum, Paris. 


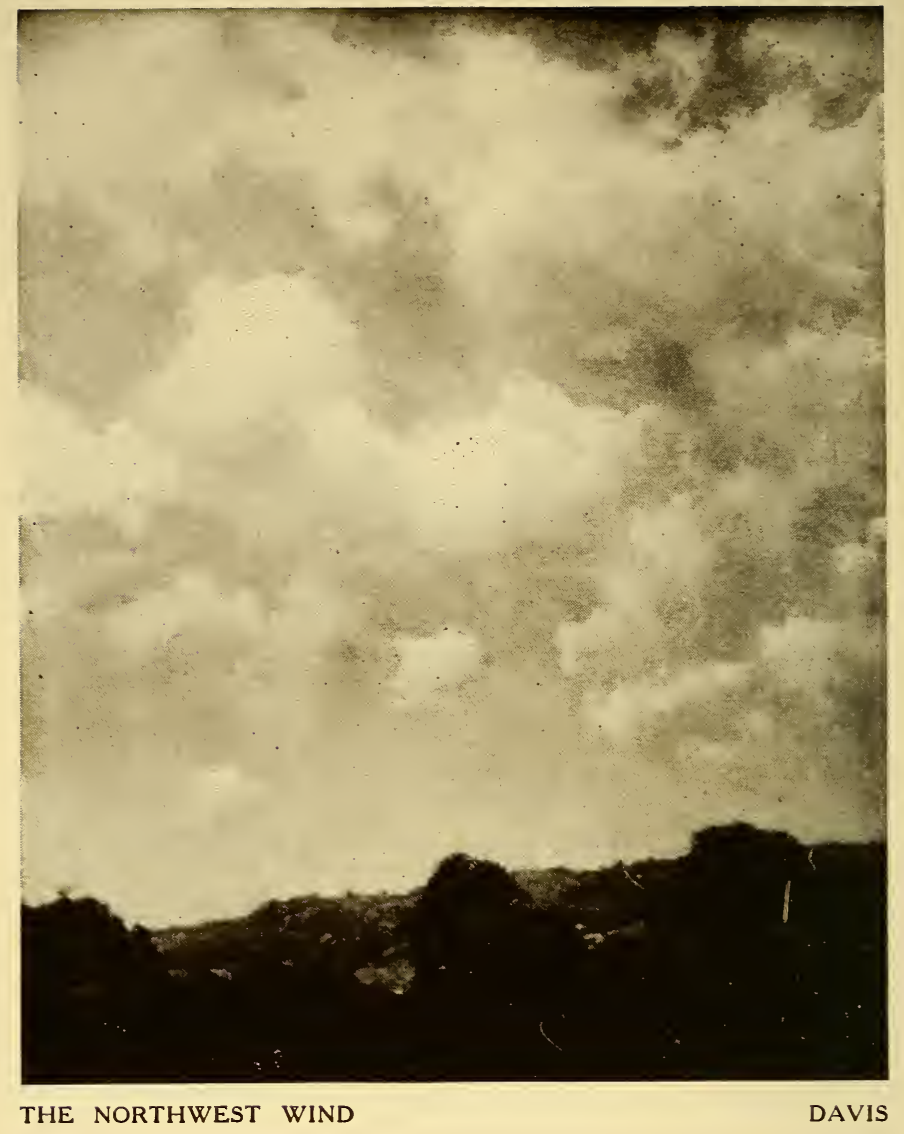




\section{CHARLES H. DAVIS}

Charles H. Davis was born in Amesbury, Massachusetts, January 7, I 856. He was a pupil of Otto Grundmann and Boston Museum School; Boulanger and Lefebvre in Paris. A member of SAA I886; ANA I901; NA I906; Copley S; Lotos C.

Awards: Gold medal, American Art. Assoc., New York I 886 ; hon. mention, Paris Salon, I $887 ; \$ 2,000$ prize, American Art Assoc., New York, I 887; silver medal, Paris Exp., I 889; hors concours, Paris Salon; Palmer prize, AIC I 890; medal, Mass. Charitable Mechanics Assoc., Boston, I 890; medal, Columbian Exp., Chicago I 893; grand gold medal, Atlanta Exp., I 895 ; bronze medal, Paris Exp., I900; Lippincott prize, PAFA I90I; silver medal, Pan-Am. Exp., Buffalo, I90I; second Corcoran prize, S. Washington A, I902; silver medal, St. Louis Exp., I904; Harris bronze medal (\$300), AIC 1914; gold medal, P.-P. Exp., San Francisco, I9I 5 .

WORK: "August" and "Evening," Metropolitan Museum, New York, N. Y.; "The Deepening Shadows," Corcoran Gallery, Washington, D. C.; "Moonrise at Twilight," Carnegie Institute, Pittsburgh, Pa.; "Clouds," Museum of Fine Arts, Boston, Mass.; "At Sunset," Art Museum, Worcester, Mass.; "Summer," National Gallery, Washington, D. C.; "The Brook," Pennsylvania Academy of the Fine Arts, Philadelphia, Pa.; "Close of Day" and "Twilight," Art Institute, Chicago, Ill.; "In April," Hackley Art Gallery, Muskegon, Michigan; "Early Summer," Minneapolis Institute of Arts. 


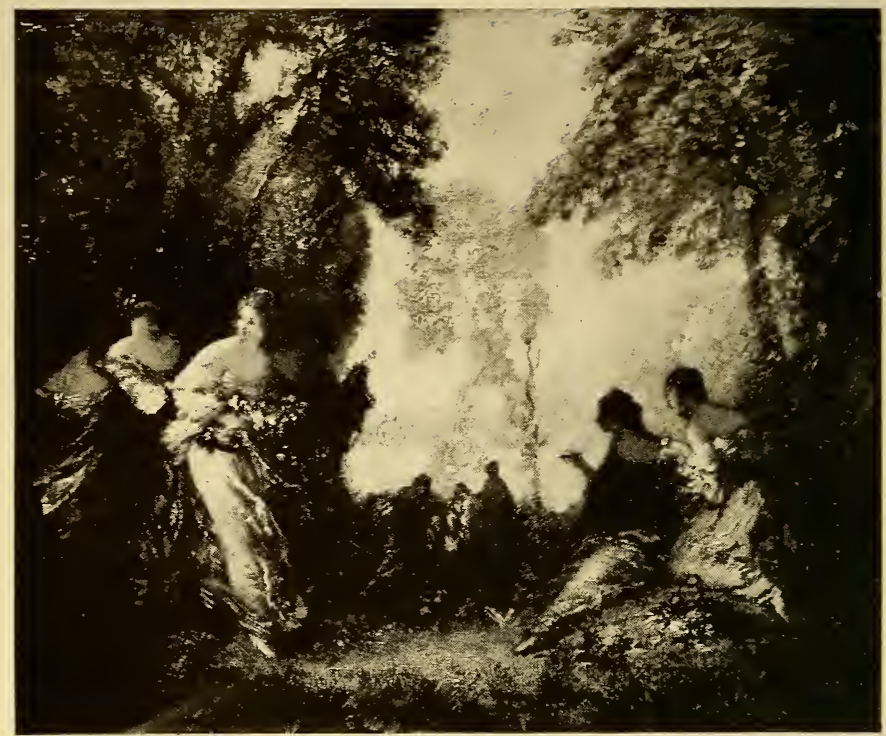

FETE BY THE LAKE

WILLIAMS

\section{FREDERICK B. WILLIAMS}

Frederick Ballard Williams was born in Brooklyn, N. Y., October 21, I87I. He was a pupil of Cooper Union and NAD in New York. A member of ANA 1907; NA 1909; NYWCC; Lotos C.; Salma. C. I898; NAC.

Awards: Bronze medal, Pan-Am. Exp., Buffalo, I90ı; Inness prize, Salma. C. 1907 ; Isidor gold medal, NAD 1909.

WORK: "A Glade by the Sea" and "Conway Hills," National Gallery, Washington; "Happy Valley" and "L'Allegro," Metropolitan Museum, New York; "Vivacetto," Albright Art Gallery, Buffalo; "Chant d'Amour," Brooklyn Institute Museum; "Old Viaduct at Little Falls, N. J." and "Sea Echoes," Art Museum, Montclair, N. J.; "Grand Canyon," Hackley Art Gallery, Muskegon, Mich.; "Spring," Brooklyn Institute Museum. 


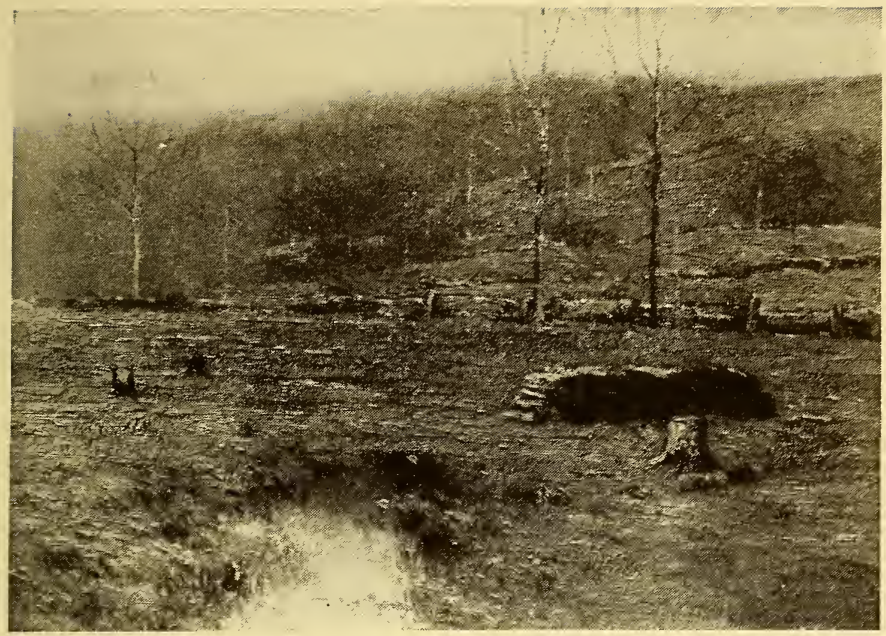

EARLY WINTER, WESTCHESTER COUNTY, N. Y.

CRANE

\section{BRUCE CRANE}

Bruce Crane was born in New York, N. Y., October I7, I 857. He was a pupil of A. H. Wyant and a member of ANA I897. NA I90I; SAA I88I ; AWCS;A. Fund S; Salma. C. I 888; Lotos C; Union Internationale des BeauxArts et des Lettres.

Awards: Webb prize, SAA i 897 ; bronze medal, Paris Exp., I900; Inness medal NAD I9OI; silver medal, PanAm. Exp., Buffalo, I90I ; silver medal, Charleston Exp., I902; gold medal, St. Louis, Exp., I904; third prize, C. I. Pittsburgh I909; Saltus medal, NAD I912; silver medal, P.-P. Exp., San Francisco, I9I 5.

Work: "Autumn Uplands," Metropolitan Museum, New York; "November Hills," Carnegie Institute, Pittsburgh; "Autumn," National Gallery, Washington; "March" Brooklyn Institute Museum; "Autumn Hills," Montclair (N. J.) Gallery; "Springtime," Peabody Institute, Baltimore; "November Hillsides," Corcoran Gallery, Washington, D. C. ; "Last of Winter," Fort Worth (Tex.) Museum; "Autumn Meadowland," Hackley Art Gallery, Muskegon, Michigan. 


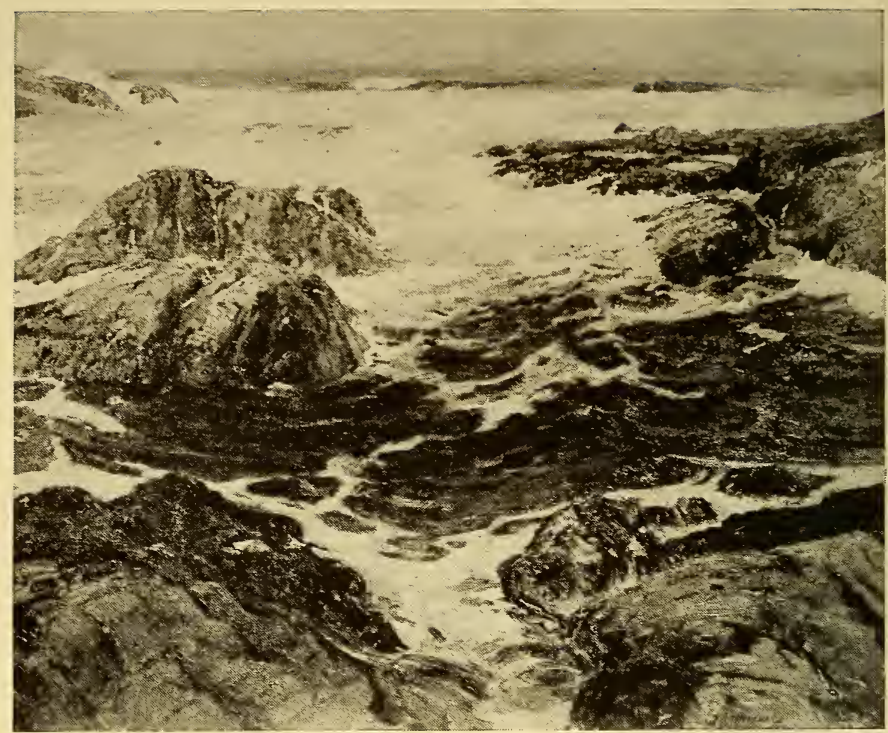

THE PLAY OF THE WAVES

RITSCHEL

\section{WILLIAM RITSCHEL}

William Ritschel was born in Nuremberg, Germany, July I I, I 864. He was a pupil of F. Kaulbach and C. Raupp in Munich; came to U. S. in I 895. He was a member of ANA I9ıо; NA I9I4; NYWCC; AWCS; Salma. C. I90ı; A. Fund S.; NAC; Kunstverein, Munich.

Awards: Hon. mention, Salma, C.; Hon. mention, CI Pittsburgh, I912; Carnegie prize, NAD I9I3; gold medal and \$I,000, NAC I9I4; gold medal, P.-P. Exp., San Francisco, I9I 5 .

Work: "Rocks and Breakers," Pennsylvania Academy of the Fine Arts; "Desert Wanderer," Art Institute. 


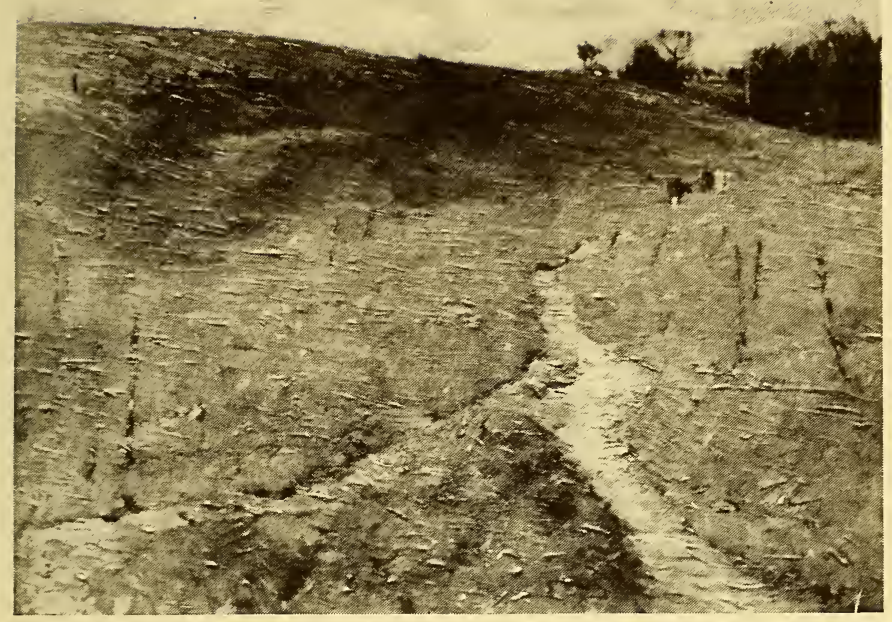

GOLDEN FIELDS

LATHROP

\section{WILLIAM LATHROP}

William Langson Lathrop was born in Warren, Illinois, March 29, I859. He was a member of ANA I902; NA 1907; NYWCG.

Awards: Evans prize, AWCS I896; gold medal ACP Phila. I 897; Webb prize, SAA I 899; bronze medal, PanAm. Exp., Buffalo, I90I ; third prize $(\$ 500)$, CI Pittsburgh, I903; second prize, Worcester, I904; bronze medal, St. Louis Exp., 1904; gold medal for oil painting and silver medal for water colors, P.-P. Exp., San Francisco, 1915.

Work: “The Meadows," Metropolitan Museum, New York; "Clouds and Hills," Minneapolis Museum; "Three Trees" National Museum of Art, Washington; "Abandoned Quarry," Carnegie Institute, Pittsburgh; "Old Covered Bridge," Hackley Art, Gallery, Muskegon, Michigan. 
SMITHSONIAN INSTITUTION LIBRARIES 